\title{
Spatial structuring and life history connectivity of Antarctic silverfish along the southern continental shelf of the Weddell Sea
}

\author{
Jilda Alicia Caccavo ${ }^{1,2, *}$, Julian R. Ashford ${ }^{3}$, Svenja Ryan ${ }^{1}$, Chiara Papetti ${ }^{4,5}$, \\ Michael Schröder ${ }^{1}$, Lorenzo Zane ${ }^{4,5}$ \\ ${ }^{1}$ Alfred Wegener Institute, Helmholtz Center of Polar and Marine Research, Bremerhaven 27570, Germany \\ ${ }^{2}$ Berlin Center for Genomics in Biodiversity Research (BeGenDiv), Berlin 14195, Germany \\ ${ }^{3}$ Department of Ocean, Earth and Atmospheric Sciences, Center for Quantitative Fisheries Ecology, Old Dominion University, \\ Norfolk, VA 23508, USA \\ ${ }^{4}$ Department of Biology, University of Padua, Padua 35121, Italy \\ ${ }^{5}$ Consorzio Nazionale Interuniversitario per le Scienze del Mare (CoNISMa), Rome 00196, Italy
}

\begin{abstract}
A multi-disciplinary approach was employed to examine a physical-biological population hypothesis for a critical forage species, the Antarctic silverfish Pleuragramma antarctica. Caccavo et al. $(2018 ;$ Sci Rep 8:17856) had shown strong gene flow along the westward Antarctic Slope Current, in addition to spatially recurring length modes that provided evidence for episodic connectivity. In this paper, otolith nucleus chemistry from a subset of fish collected in the southern Weddell Sea as part of a hydrographic survey of the Filchner Trough system was used to test between connectivity scenarios. Nucleus chemistry, which reflects environmental exposure during early life, showed significant spatial structuring despite homogeneity in microsatellite allele frequencies. $\mathrm{Mg}: \mathrm{Ca}$ and $\mathrm{Sr}: \mathrm{Ca}$ differentiated length modes, and $\mathrm{Mg}: \mathrm{Ca}$ showed significant contrasts between Atka Bay, Halley Bay, and Filchner Trough. Physical-biological mechanisms may help reconcile structuring shown by otolith chemistry, length, and abundance data with prior evidence of gene flow. Such mechanisms include self-recruitment shaped by circulation associated with the Filchner Trough, fluctuations in mixing between immigrant and locally recruited fish, and feeding opportunities between inflowing Modified Warm Deep Water and outflowing Ice Shelf Water. The results illustrate how comparisons between multi-disciplinary techniques based on integrated sampling designs that incorporate hydrography can enhance understanding of population structure and connectivity around the Southern Ocean.
\end{abstract}

KEY WORDS: Physical-biological interactions $\cdot$ Filchner Trough $\cdot$ Population structure $\cdot$ Life history connectivity · Trough circulation · Modified Warm Deep Water · MWDW · Ice Shelf Water · ISW $\cdot$ Otolith chemistry

\section{INTRODUCTION}

\subsection{Life history and along-shelf connectivity}

Antarctic silverfish Pleuragramma antarctica (Fig. 1) have a circumpolar distribution and, as an important forage species, perform a critical role connecting higher and lower trophic levels in Southern Ocean

\footnotetext{
${ }^{*}$ Corresponding author: ergo@jildacaccavo.com
}

shelf ecosystems (Duhamel et al. 2014, Koubbi et al. 2017). Despite lacking a swim bladder, silverfish are pelagic throughout their life history, including a cryopelagic egg and early larval phase, maintaining neutral buoyancy by sequestration of lipids in large storage sacs (Eastman \& DeVries 1989, La Mesa \& Eastman 2012). Similar to related benthic notothenioids, Antarctic silverfish are inactive, remaining

(C) The authors 2019. Open Access under Creative Commons by Attribution Licence. Use, distribution and reproduction are unrestricted. Authors and original publication must be credited. 


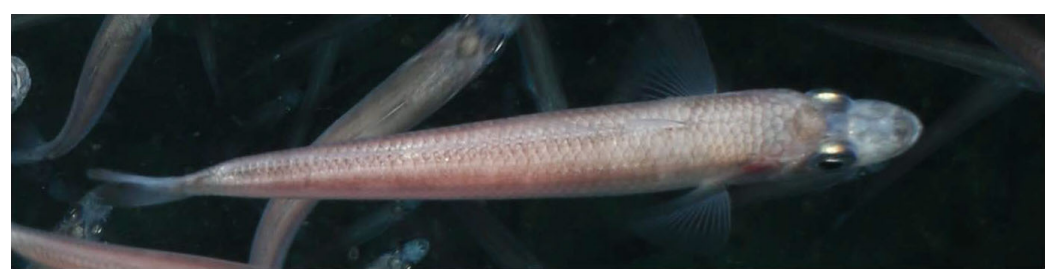

Fig. 1. The Antarctic silverfish Pleuragramma antarctica (Piepenburg 2016) the Antarctic, Caccavo et al. (2018) tested the along-shelf component of the physical-biological hypothesis, finding evidence of strong circumpolar gene flow. The Antarctic Slope Front (ASF) separates warm, saline oceanic water masses at mid-depth from colder, fresher shelf waters, and the horizontal pressure gradient generated is associsuspended in the water column to feed (Wöhrmann et al. 1997). These life history and behavior characteristics accentuate silverfish interactions with current and front systems that potentially play a key role in maintaining connectivity between areas along the Antarctic continental shelf (Ashford et al. 2017).

Early development of silverfish in the platelet ice layer beneath coastal fast ice (Vacchi et al. 2004) is followed by advection of larvae over the shelf during the austral summer and descent into deeper waters as juveniles and adults (La Mesa et al. 2010, Guidetti et al. 2015). Mature silverfish inhabit depths from 400-700 m (La Mesa \& Eastman 2012) and exhibit diurnal vertical migration (Lancraft et al. 2004). Life history structured by circulation associated with glacial trough systems has been hypothesized (Ashford et al. 2017) for areas where early life stages of silverfish have been found around the Antarctic (Ghigliotti et al. 2017), including the Ross Sea (Guglielmo et al. 1997), Antarctic Peninsula (Kellermann 1986), Dumont d'Urville Sea (Koubbi et al. 2011), and Weddell Sea (Hubold 1984). In this physical-biological population hypothesis, fish entrained in the trough outflow are carried offshore towards the continental shelf-break, where mixing with inflowing water masses carries a proportion back inshore. Fish reaching the continental shelf-break become exposed to currents along the continental slope, which transport them to trough systems downstream (Ashford et al. 2017). Brooks et al. (2018) examined the cross-shelf component of the hypothesis by comparing samples of larvae caught along the outflow and inflow of the Drygalski Trough in the western Ross Sea. They found evidence supporting a unified population spatially constrained by cryopelagic incubation under fast ice at the head of the trough. Thus, after hatching in December-January, larvae were found in large numbers in the trough outflow and inflow during February-March, whereas few were found elsewhere in the western Ross Sea (Brooks et al. 2018).

Along the continental shelf, low levels of heterogeneity have been shown using mitochondrial DNA (Zane et al. 2006) and microsatellite markers (Caccavo et al. 2018). Comparing multiple areas around ated with westward flow in the Antarctic Slope Current (ASC) (Orsi et al. 1995, Whitworth et al. 1998). The ASF and associated ASC is detectable from the Amundsen Sea west around East Antarctica to the Hesperides Trough north of the Antarctic Peninsula (see Fig. 1 in Caccavo et al. 2018 for a full treatment of place names outside the area of the present study), and plays an important role regionally in mediating the transport of warm water onto the shelf (Azaneu et al. 2017, Thompson et al. 2018). Analyzing silverfish from shelf areas along the ASC, Caccavo et al. (2018) found no significant differences in allele frequencies from the Ross Sea to the northern Antarctic Peninsula. However, regions where levels of gene flow were reduced corresponded to discontinuities in the large-scale circulation. East of the Hesperides Trough, fish over the South Orkney shelf differentiated from those associated with the ASC (Caccavo et al. 2018). Moreover, fish from both the ASC and South Orkney Islands showed distinct patterns of differentiation from others sampled along the western Antarctic Peninsula, where the southern Antarctic Circumpolar Current (ACC) flows eastward along the continental slope (Orsi et al. 1995, Savidge \& Amft 2009).

Inshore, the Antarctic Coastal Current (AACC) occupies the upper part of the water column and transports fresh shelf waters westward. Freshwater input from precipitation, run-off, sea ice, and glacial melt influence its presence and strength, which varies spatially, seasonally, and inter-annually (Moffat et al. 2008, Dutrieux et al. 2014). Off the eastern Antarctic Peninsula, the AACC merges with the ASC and then separates again around Joinville Island (Thompson et al. 2009). Caccavo et al. (2018) showed gene flow from the northern Antarctic Peninsula to the South Shetland Islands, corresponding to the AACC where it forms the southern boundary of the Bransfield Gyre (Savidge \& Amft 2009). Another area where flow in the AACC and the ASC merge is along the narrow shelf in the eastern Weddell Sea (Graham et al. 2013), where Caccavo et al. (2018) found no genetic differentiation between Atka Bay and further west in Halley Bay and Filchner Trough. Neverthe- 
less, extensive plankton sampling throughout the region found discontinuous distributions of silverfish larvae associated with troughs off Camp Norway and the Filchner Ice Shelf (Hubold 1984), suggesting spatially separated populations (Ashford et al. 2017).

Regionally, westward flow is forced by prevailing easterly winds (Heywood et al. 1998): increased wind speeds in autumn coincide with freshening shoreward of the ASC off the Riiser-Larsen Ice Shelf (Fig. 2) and the arrival of the previous summer's melt from sea ice off the Fimbul Ice Shelf upstream (Graham et al. 2013). Downstream, the continental shelf widens, and the flow of the ASC splits into 2 branches (Fig. 2). The first branch follows the coast in Halley Bay south past the Brunt Ice Shelf (Nicholls et al. 2009), connecting flow along the continental shelf-break to the inner shelf, and carrying relatively fresh Eastern Shelf Water (ESW) southward along the eastern shelf adjoining the Filchner Trough (Fig. 2) (Nicholls et al. 2009). The second branch continues westward along the continental slope carrying Modified Warm Deep Water (MWDW) towards Filchner Trough. MWDW is formed as a result of mixing across the ASC, between Warm Deep Water (WDW) carried along the continental slope in the ASC at intermediate depth and a layer of Winter Water (WW) above. WDW is a derivative of Circumpolar Deep Water (CDW) that is very nutrient rich but poor in oxygen; transported within the ACC, the CDW is injected into the Weddell Gyre at its eastern boundary (Ryan et al. 2016). Intrusions of MWDW are found over the shelf off Camp Norway during winter (Graham et al. 2013); further downstream, warm on-shore flow is observed during summer, due to weaker along-coast wind stress in summer, which causes a relaxation of the ASC (Årthun et al. 2012, Darelius et al. 2016, Ryan et al. 2017). MWDW is transported across the shelf-break east of the Filchner Trough and flows southward over the shelf along its eastern flank and offshore of the AACC (Nicholls et al. 2009, Ryan et al. 2017), providing a second, deeper pathway connecting the continental slope to the inner shelf (see Figs. 2 \& 3 in Ryan et al. 2017). The Filchner Trough is filled with Ice Shelf Water (ISW), which emerges from the Filchner Ice Shelf cavity and has temperatures below the surface freezing point. It is transported northward above the eastern slope of the Filchner Trough and exits the trough across the sill, contributing to deep water formation within the Weddell Sea. In winter, southward flow of MWDW ceases, and the ISW layer in the trough extends on to the adjacent eastern shelf (Ryan et al. 2017).

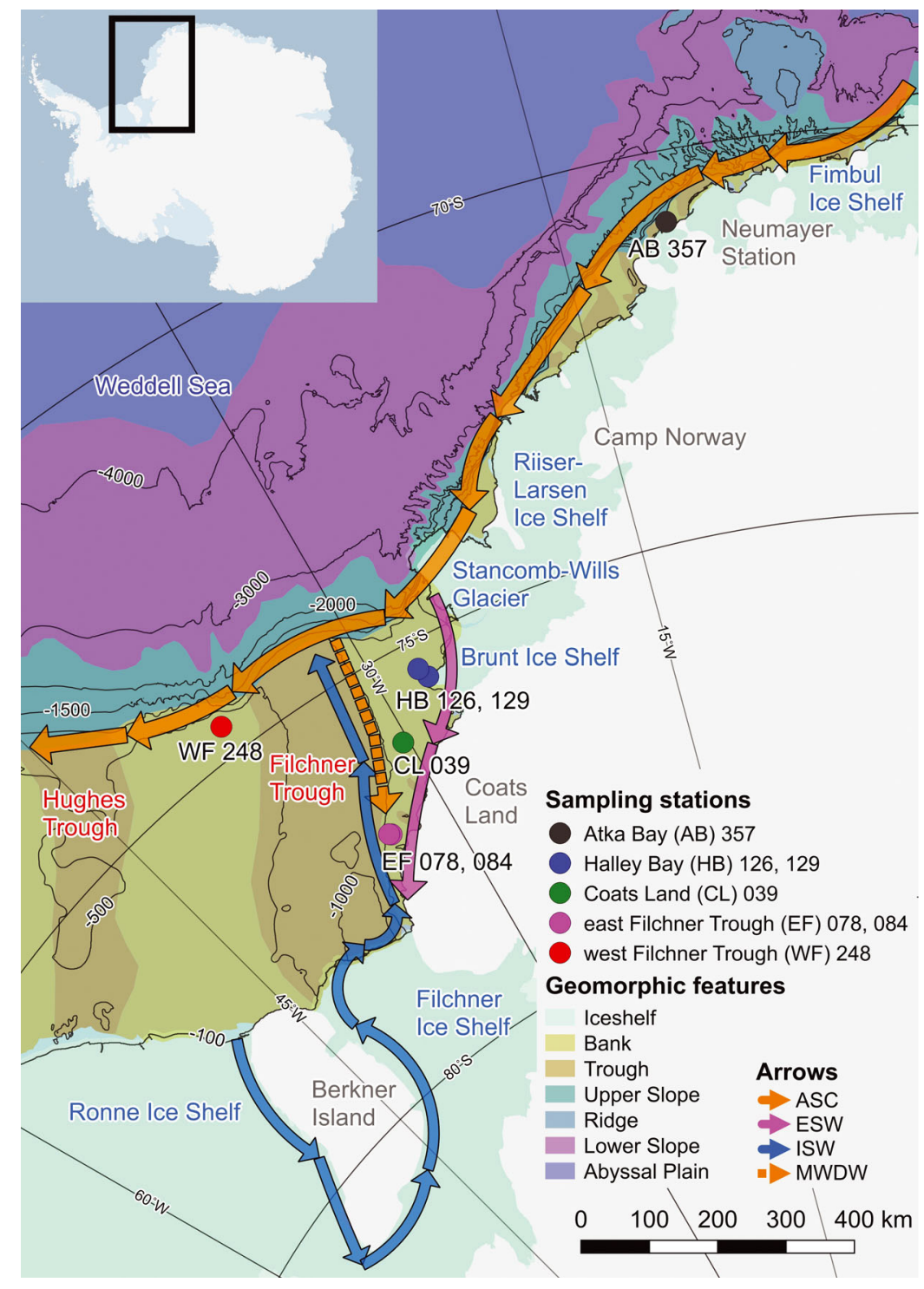

Fig. 2. Sampling areas and station numbers in relation to major hydrographic features. Circulation based on Fig. 2b in Nicholls et al. (2009) and Fig. 1 in Ryan et al. (2017). ASC: Antarctic Slope Current; ESW: Eastern Shelf Water; ISW: Ice Shelf Water; MWDW: Modified Warm Deep Water. Map created with Quantarctica v.3.0 (Matsuoka et al. 2018) using QGIS v.2.18.9 (QGIS Development Team 2018) 


\subsection{Testing population structure along the continental shelf}

Several studies have implicated structuring and connectivity between Antarctic silverfish by current and front systems. As well as noting that fish reaching the ASC in the Ross Sea become exposed to along-shelf connectivity, Brooks et al. (2018) suggested that larvae found in the Bay of Whales may have been spawned by fish transported along the AACC from the eastern Amundsen Sea. Caccavo et al. (2018) found, in addition to regional connectivity along the ASC, evidence of a recent influx of silverfish in the inflow of Marguerite Trough off the western Antarctic Peninsula. This was consistent with an earlier review by Kellermann (1996), who suggested that fish spawned in the Bellingshausen Sea were advected over the western Antarctic Peninsula shelf via slope transport in the ACC. Genetics data also indicated connectivity via the AACC between silverfish found in Marguerite Bay and Charcot Island (Agostini et al. 2015), which was further supported by reproductive data (La Mesa et al. 2015b), otolith chemistry (Ferguson 2012), community spatial distributions (Parker et al. 2015), and particle simulations based on a circulation model for the southwestern Antarctic Peninsula shelf (Piñones et al. 2011). Additionally, particle simulations combined with otolith age data suggested that larvae sampled off Joinville Island were spawned in Larsen Bay in the western Weddell Sea, before being transported around the northern Antarctic Peninsula and into the Bransfield Gyre via the AACC (La Mesa et al. 2015a).

In the Weddell Sea, White \& Piatkowski (1993) noted that dense larval distributions found over the continental slope east of the Filchner Trough mouth were consistent with an earlier hypothesis of westward dispersal by surface currents (Hubold 1984). Much of the evidence for the role of hydrography in connectivity between silverfish populations has been derived from indirect observation using monodisciplinary approaches (Hubold 1984, Kellermann 1986, 1996, Agostini et al. 2015, Brooks et al. 2018). Yet multi-disciplinary studies can allow cross-corroboration and comparison between complementary techniques (Begg et al. 1999, Sturrock et al. 2012), while understanding of the physical context can help to directly address the role of physical-biological interactions in structuring silverfish populations (Ashford et al. 2017, Davis et al. 2017, Brooks et al. 2018). This allows for connectivity hypotheses to be tested between neighboring populations in which the inter- play between local hydrographic features and life history is important (Ashford et al. 2017). In this context, the genetic homogeneity observed by Caccavo et al. (2018) along the ASC must be reconciled with length distributions, which vary around the Antarctic (Ferguson 2012, Caccavo et al. 2018) and are indicative of spatial structuring. Given that all life stages of silverfish are pelagic and are thus exposed to circulation across and along the shelf, the level of exchange of individuals between otherwise demographically distinct populations typically homogenize any existing genetic differentiation between areas (Palsbøll et al. 2007, Lowe \& Allendorf 2010). Moreover, modes in length distribution often recurred between sampling areas, notably in the southern Weddell Sea (Caccavo et al. 2018). This could be explained by westward dispersal predicted by White \& Piatkowski (1993) from shelf areas upstream, with episodic influxes shaped by inter-annual variation in transport along and across the continental shelf.

The integration of multiple fisheries population techniques allows for synergies that ultimately strengthen the understanding of population structure and demography (Welch et al. 2015). Such approaches can be highly flexible, with selection of techniques and sampling designs targeted to test precise spatial predictions from physical-biological hypotheses (La Mesa et al. 2015a, Ashford et al. 2017, Brooks et al. 2018). Analysis of trace element deposition in fish otoliths has been shown to successfully resolve population structure in marine species based on distinct otolith nucleus chemistry indicative of disparate environmental exposure in early life (Campana et al. 1994, Campana 1999, Ashford et al. 2006, Thorrold \& Swearer 2009). While allele frequency distributions highlight population processes on a multi-generational timescale and length distributions can indicate spatial structuring at the time of sampling, otolith chemistry records environmental and physiological influences over an individual's life history. Otolith chemistry, therefore, has the potential to resolve population structure where gene flow homogenizes genetic differences, and throw light on the mechanisms explaining spatial length distributions and genetic connectivity (Ashford et al. 2006, Taillebois et al. 2017).

Using chemistry deposited at the otolith edge directly prior to capture, spatial discrimination has been empirically tested between sampling areas around the maritime Antarctic and southern South America (Ashford et al. 2005), as well as across frontal systems within the ACC (Ashford et al. 2007), and along the continental slope off the Ross Sea 
(Ashford et al. 2012). Chemistry deposited in otolith nuclei during early life has been used to successfully test population hypotheses in multiple notothenioid species: Patagonian toothfish Dissostichus eleginoides (Ashford et al. 2006), Scotia Sea icefish Chaenocephalus aceratus (Ashford et al. 2010), Antarctic toothfish Dissostichus mawsoni (Ashford et al. 2012), as well as Antarctic silverfish (Ferguson 2012). Ratios of trace and minor elements to Ca have been empirically shown to corroborate genetic differences found between geographic areas (Ashford et al. 2006, 2008, 2012), including direct comparison of genetic and otolith markers from the same fish (Shaw et al. 2004, Ashford et al. 2006). The important markers around the Southern Ocean and the Antarctic continental shelf described so far are $\mathrm{Mg}: \mathrm{Ca}, \mathrm{Sr}: \mathrm{Ca}$ and $\mathrm{Ba}: \mathrm{Ca}$, all of which have detected spatial structuring (Ashford et al. 2010, 2012, Zhu et al. 2018). While Mn:Ca discriminated fish from either side of fronts in the ACC off South America (Ashford et al. 2005, 2006), it was found to be nearly absent at higher southern latitudes.

Although the physiological mechanisms involved have yet to be fully described, differences in $\mathrm{Ba}: \mathrm{Ca}$ are thought to reflect ambient levels of dissolved $\mathrm{Ba}$ (Campana et al. 1994, Ashford et al. 2005), consistent with barite accumulation resulting from nitrate production and transport to depth in the ACC (Dehairs et al. 1992). In contrast, $\mathrm{Mg}: \mathrm{Ca}$ and $\mathrm{Sr}: \mathrm{Ca}$ are directly influenced by physiology: $\mathrm{Sr}: \mathrm{Ca}$ is thought to reflect growth (Campana 1999), mediated by ambient temperature and food availability associated with water masses like WDW and ISW, whereas Mg:Ca is associated with physiological processes related to fish activity like reproduction and movement, again influenced by spatially variable properties of the ambient water (Ashford et al. 2005, 2010, 2012, Zhu et al. 2018). Similarly, high levels of otolith $\mathrm{Mn}: \mathrm{Ca}$ off southeastern South America may be linked to physiology and exposure to effluxes from anoxic sediments resulting from authigenic Mn activity (Ashford et al. 2005).

In this study, we examined the physical-biological hypothesis of Ashford et al. (2017) using otolith nucleus chemistry from fish already analyzed genetically by Caccavo et al. (2018). We used samples taken in the southeastern Weddell Sea between Atka Bay and Filchner Trough characterized by strong spatially recurring modes in their length distributions. Material from otolith nuclei was compared to test between 3 scenarios: (1) one homogeneous population implying a shared natal trough, (2) independent populations associated with spatially separated trough systems, and (3) episodic connectivity associated with the ASC and AACC along the southern Weddell shelf. A shared early life history would be expected to generate similar nucleus chemistry, whereas significant differences between sampling areas would be consistent with spatial structuring, and differences between modes consistent with episodic influxes of fish from troughs along the shelf.

\section{MATERIALS AND METHODS}

\subsection{Field sampling}

Antarctic silverfish were collected in the southern Weddell Sea in January and February 2014 as part of the research cruise PS82 (ANT-XXIX/9) by the RV 'Polarstern', investigating the Filchner Outflow System. For this research, a Seabird 911+ CTD, measuring salinity, temperature, and pressure, attached to a carousel with 24 water bottles, was deployed to investigate the physical environment in the region around the Filchner Trough, including the course of the AACC and MWDW flowing towards the Filchner Ice Shelf (Knust \& Schröder 2014). Conductivity and temperature sensors were calibrated before and after the cruise by Seabird Electronics; in addition, conductivity was corrected after calibration using salinity measurements from water samples measured by 2 Optimare Precision salinometers. A total of 142 CTD profiles were obtained for oceanographic transects across and along the continental slope and shelfbreak, and across the eastern shelf adjoining the trough (see Fig. 3). The distribution of bottom water masses over the slope and continental shelf were reported by Schröder et al. (2014). The CTD section at $76^{\circ} \mathrm{S}$ off Coats Land was described by Ryan et al. (2017), including seasonal evolution based on a $2 \mathrm{yr}$ time series retrieved from 3 moorings.

Integrated with the physical measurements, silverfish were sampled from stations around the Filchner Trough including the adjoining eastern shelf. All sampling was undertaken during the day when fish were near the bottom during their diurnal migration (Fig. 2, Table 1, Fig. S1a), using a commercial benthic trawl with a cod-end mesh line of $20 \mathrm{~mm}$. Standard length (SL) was measured for all individuals, and biomass, abundance, and size distribution determined for each haul. Catches were randomly sub-sampled for tissue and otoliths for subsequent analyses. For comparison, samples were also collected in Atka Bay and off Camp Norway, with corresponding CTD data. 


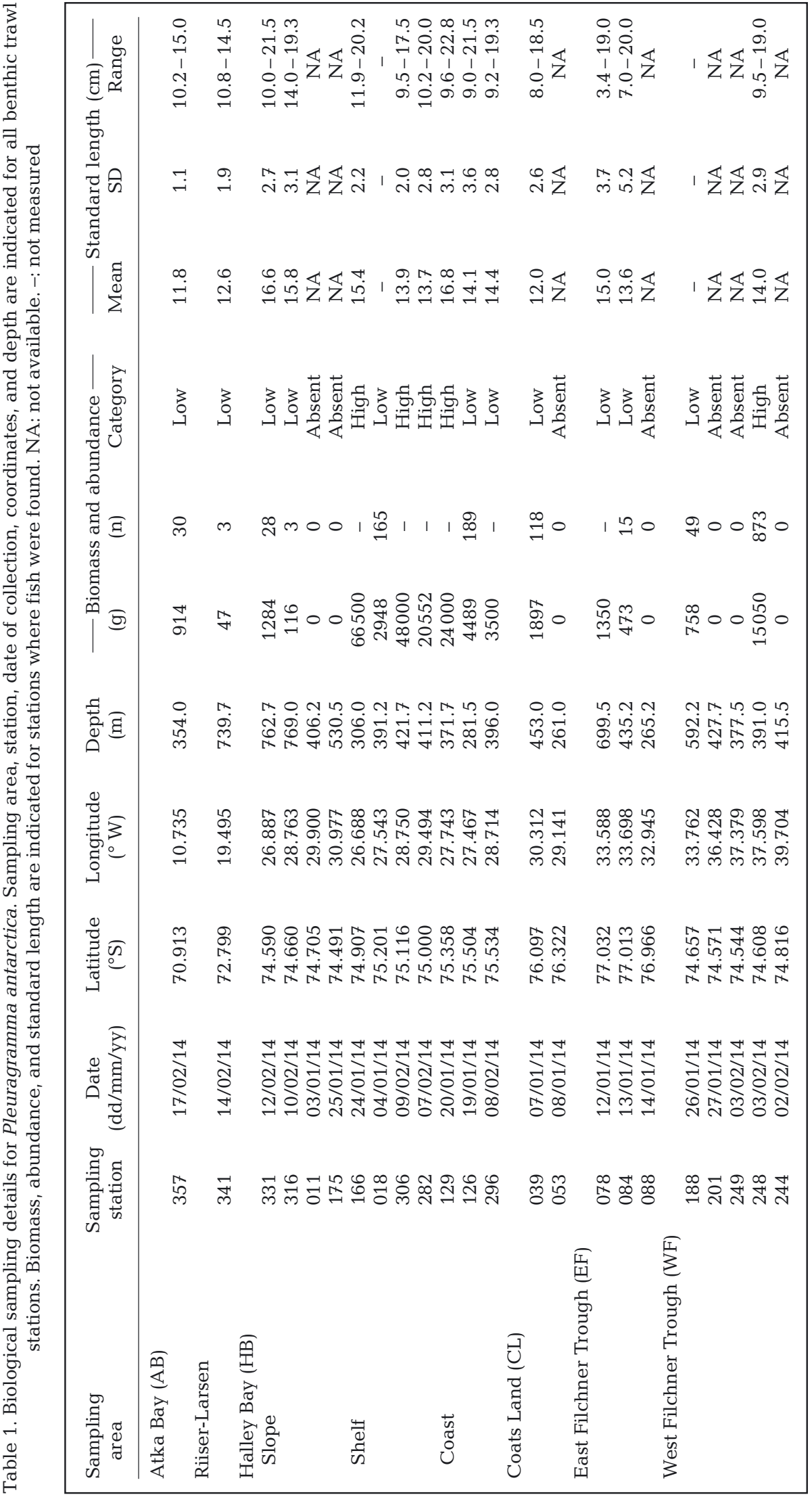

\subsection{Laboratory procedures}

Biomass and abundance indices of Antarctic silverfish were reported by Wetjen et al. (2014a) and Wetjen et al. (2014b), and genetic analyses were undertaken and reported by Caccavo et al. (2018). Length distributions showed 2 recurrent modes: immature fish at approximately $10 \mathrm{~cm}$ and mature fish at approximately $15 \mathrm{~cm}$ SL. However, the length modes were not uniformly present at every sampling area, precluding a cross-wise experimental design with area and length group as factors. Instead, 5 stations were selected along the shelf in relation to the position of the AACC, the ASC, and inflows across the shelf-break. These were (1) in Atka Bay; along the eastern shelf adjoining Filchner Trough corresponding to 3 CTD sections (2) across Halley Bay; (3) at $76^{\circ} \mathrm{S}$ off Coats Land; (4) at $77^{\circ} \mathrm{S}$ just east of the trough flank; and (5) near the shelf-break corresponding to a section across the western shelf downstream of the trough mouth (see Table 2, Fig. 2). All fish in a given sampling area were pooled where only one mode was present; where both were present, fish were pooled into groups of large and small individuals. A cutoff of $13 \mathrm{~cm}$ was used to separate the length modes of 10 and $15 \mathrm{~cm}$, corresponding approximately to the length at which sexual maturation begins in males and females (La Mesa \& Eastman 2012). This resulted in 8 groups from each of which 25 fish were randomly sub-sampled to form experimental treatments. In Halley Bay, both large and small groups at Stn 126 were supplemented by randomly selected fish from nearby Stn 129. Similarly at $77^{\circ} \mathrm{S}, 6$ fish from 
Stn 84 supplemented those sampled from Stn 78, resulting in 8 treatments: Atka Bay (AB), Halley Bay small mode (HB-S) and large mode (HB-L), Coats Land small (CL-S) and large (CL-L) mode, East Filchner Trough (EF), West Filchner Trough small (WF-S) and large (WF-L) mode (Table 2).

One randomly selected otolith from each fish was used for elemental analysis. Otoliths were prepared using a standard protocol developed at the Center for Quantitative Fisheries Ecology at Old Dominion University. They were initially cleaned using glass probes and rinsed in Milli-Q water. Any remaining surface contamination was removed by $5 \mathrm{~min}$ incubation in $20 \%$ Ultra-Pure hydrogen peroxide, followed by rinsing in Milli-Q water. Otoliths were then mounted onto slides using crystal bond, and ground from the anterior side using a Crystal Master 8 Machine with 3-micron $3 \mathrm{M}^{\mathrm{TM}}$ polishing film to reveal a transverse surface just above the primordium. In a clean room, mounted otoliths were given a final polish by hand to reveal the primordium using 3-micron $3 \mathrm{M}^{\mathrm{TM}}$ polishing film, and once again rinsed with Milli-Q water and allowed to dry. Otoliths were removed from the polishing slide and mounted on petrographic slides in a randomized block design, with slide as the blocking factor. In this way, all 8 treatments were represented on each petrographic slide, and the slides were then rinsed and sonicated individually for $5 \mathrm{~min}$ in Milli-Q water before placement under a laminar-flow hood to dry.

Minor and trace elements were measured using a Finnegan Mat Element 2 double-focusing sector-field inductively coupled plasma mass spectrometer (ICPMS) located in the Plasma Mass Spectrometry Facility at Woods Hole Oceanographic Institution (WHOI). Samples were introduced into the ICP in an automated sequence (Chen et al. 2000) in which otolith material ablated with a $193 \mathrm{~nm}$ laser ablation system was combined with $\mathrm{HNO}_{3}$ aerosol introduced by a microflow nebulizer. The subsequent mixture was then carried to the ICP torch. For quality control, we used a calcium carbonate reference produced by the US Geological Survey (Microanalytics Carbonate Standard, MACS-3), for which elemental fractionation, mass-load, and matrix effects have been shown to be small for lithophile elements, especially when used with 193 nm laser ablation (Jochum et al. 2012). In the same way as the samples, MACS-3 material was ablated and introduced into the spray chamber as an aerosol $\mathrm{HNO}_{3}$ aerosol alone was also introduced into the spray chamber by the nebulizer as blanks. The randomized block design controlled for operational variability in the instrument. Blank and reference readings of count rate (count $\mathrm{s}^{-1}$ ) were taken before and after each block, and every 4 otoliths within blocks. Readings consisted of 60 scans with 200 samples peak ${ }^{-1}$ and a $5 \%$ window. Based on markers identified during previous studies for the Southern Ocean, otoliths were analyzed for ${ }^{48} \mathrm{Ca}^{25}{ }^{25} \mathrm{Mg},{ }^{55} \mathrm{Mn}$, ${ }^{88} \mathrm{Sr}$, and ${ }^{138} \mathrm{Ba}$ and reported as ratios to ${ }^{48} \mathrm{Ca}$. Background counts were subtracted from otolith counts by interpolating between the readings taken before and after every 4 otoliths, and the corrected otolith counts were then converted to element: Ca ratios using the standards. To measure ratios indicative of conditions to which fish were exposed during early life, a grid raster type $150 \times 200 \mu \mathrm{m}$ was placed over the otolith nucleus corresponding to the first austral summer of growth, during which larvae are thought to remain in their natal trough (Brooks et al. 2018). The area was ablated using a $20 \mu \mathrm{m}$ diameter laser beam at a frequency of $10 \mathrm{~Hz}$ and a power of $60 \%$, traveling over the raster at $6 \mu \mathrm{m} \mathrm{s}^{-1}$. As expected from earlier studies along the Antarctic continental shelf, Mn:Ca val-

Table 2. Pleuragramma antarctica treatment group details. Sampling area, station, acronym, sample size (n), and standard length are indicated for all samples used in the otolith analysis. NA: not available

\begin{tabular}{|c|c|c|c|c|c|c|}
\hline \multirow{2}{*}{$\begin{array}{l}\text { Sampling } \\
\text { area }\end{array}$} & \multirow{2}{*}{$\begin{array}{l}\text { Sampling } \\
\text { station }\end{array}$} & \multirow{2}{*}{$\begin{array}{l}\text { Treatment group } \\
\text { acronym }\end{array}$} & \multirow[b]{2}{*}{$\mathrm{n}$} & \multicolumn{2}{|c|}{ - Standard length $(\mathrm{cm})$} & \multirow[b]{2}{*}{ Range } \\
\hline & & & & Mean & $\mathrm{SD}$ & \\
\hline Atka Bay (AB) & 357 & $\mathrm{AB}$ & 25 & 11.7 & 1.1 & $10.2-15.0$ \\
\hline \multirow[t]{4}{*}{ Halley Bay (HB) } & 129 & HB-small (HB-S) & 4 & 11.8 & 0.5 & $11.0-12.0$ \\
\hline & & HB-large (HB-L) & 1 & 17.0 & NA & NA \\
\hline & 126 & HB-small (HB-S) & 21 & 10.4 & 1.0 & $9.0-12.5$ \\
\hline & & HB-large (HB-L) & 24 & 15.8 & 2.1 & $13.5-21.5$ \\
\hline \multirow[t]{2}{*}{ Coats Land (CL) } & 039 & CL-small (CL-S) & 25 & 10.2 & 0.9 & $9.0-12.5$ \\
\hline & & CL-large (CL-L) & 25 & 15.1 & 1.4 & $13.2-18.5$ \\
\hline \multirow[t]{2}{*}{ East Filchner Trough (EF) } & 078 & EF & 19 & 15.9 & 2.1 & $10.5-19.0$ \\
\hline & 084 & EF & 6 & 16.8 & 2.7 & $12.5-20.0$ \\
\hline \multirow[t]{2}{*}{ West Filchner Trough (WF) } & 248 & WF-small (WF-S) & 25 & 10.7 & 0.9 & $9.0-12.0$ \\
\hline & & WF-large (WF-L) & 25 & 15.7 & 1.7 & $13.0-19.0$ \\
\hline
\end{tabular}


ues were extremely low, frequently showing zero values after standard conversion. Background levels of Ba increased over the course of the analyses; however, the randomized blocks design guarded against any resulting biases.

\subsection{Statistical analysis}

Data for $\mathrm{Mg}: \mathrm{Ca}$, Sr:Ca, and Ba:Ca were checked for multivariate outliers by plotting squared Mahalanobis distances of the residuals $\left(D^{2}{ }_{i}\right)$ against the corresponding quantiles $\left(Q-Q\right.$ plot) of the $\chi^{2}$ distribution (Khatree \& Naik 1999), and none were identified. Data for $\mathrm{Mg}$ :Ca and Ba:Ca were found not to conform to multivariate normality based on tests using Mardia's multivariate skewness and kurtosis measures ( $\alpha=0.05$ ) and $Q-Q$ plots of squared Mahalanobis distances $\left(d^{2}{ }_{i}\right)$; variance-covariance matrices were not equal according to Bartlett's modification $(\alpha=0.10)$. Univariate power transformations (Ashford et al. 2007) succeeded in stabilizing the variances, with the transformed data conforming to multivariate normality with equal variance-covariance matrices. The data transformations were $y^{0.01}$ for $\mathrm{Mg}: \mathrm{Ca}$, and $y^{-1}$ for $\mathrm{Ba}$ :Ca; no transformation was required for $\mathrm{Sr}: \mathrm{Ca}$.

Once transformed data fulfilled assumptions, we tested between population hypotheses using MANOVA. Contrasts were constructed between (1) Atka Bay and Halley Bay (AB vs. HB-S + HB-L); (2) Halley Bay and Filchner Trough (HB-S + HB-L vs. CL-S + CL-L + WF-S + WF-L); and (3) large and small modes in the length distributions for areas with both modes in Halley Bay and Filchner Trough (HB-L + CL-L + WF-L vs. HB-S + CL-S + WF-S). Equal variance-covariance ratios allowed for the calculation of canonical discriminant variates for graphic illustration (Khattree \& Naik 2000). Univariate models were used to examine the influence of each element:Ca. Evaluating differences between treatments further, we also used Student-Newman-Keuls (SNK) and Scheffé tests for pairwise comparisons in an ordered array of treatment means based on experimentwise error rates.

\section{RESULTS}

\subsection{Physical data: topography and hydrography}

Generally, the Filchner Trough is filled with dense ISW, while intrusions of MWDW are observed to the east and west of the Filchner Sill (Fig. 3) (Schröder et al. 2014). Further south, the bottom layer was occupied by ISW along the eastern flank of the trough and the adjoining shelf, and ESW closer to shore. The section at $76^{\circ} \mathrm{S}$ off Coats Land showed a layer of ISW reaching onto the eastern shelf in January 2014, with a trace of MWDW at mid-depth from a southward flowing intrusion over the shelf adjoining the eastern flank of the trough (Fig. 3c) (Ryan et al. 2017).

Examining the CTD profiles (Fig. 4) for stations selected for otolith chemistry, the bottom trawl sample of fish from Atka Bay was taken from a depth of
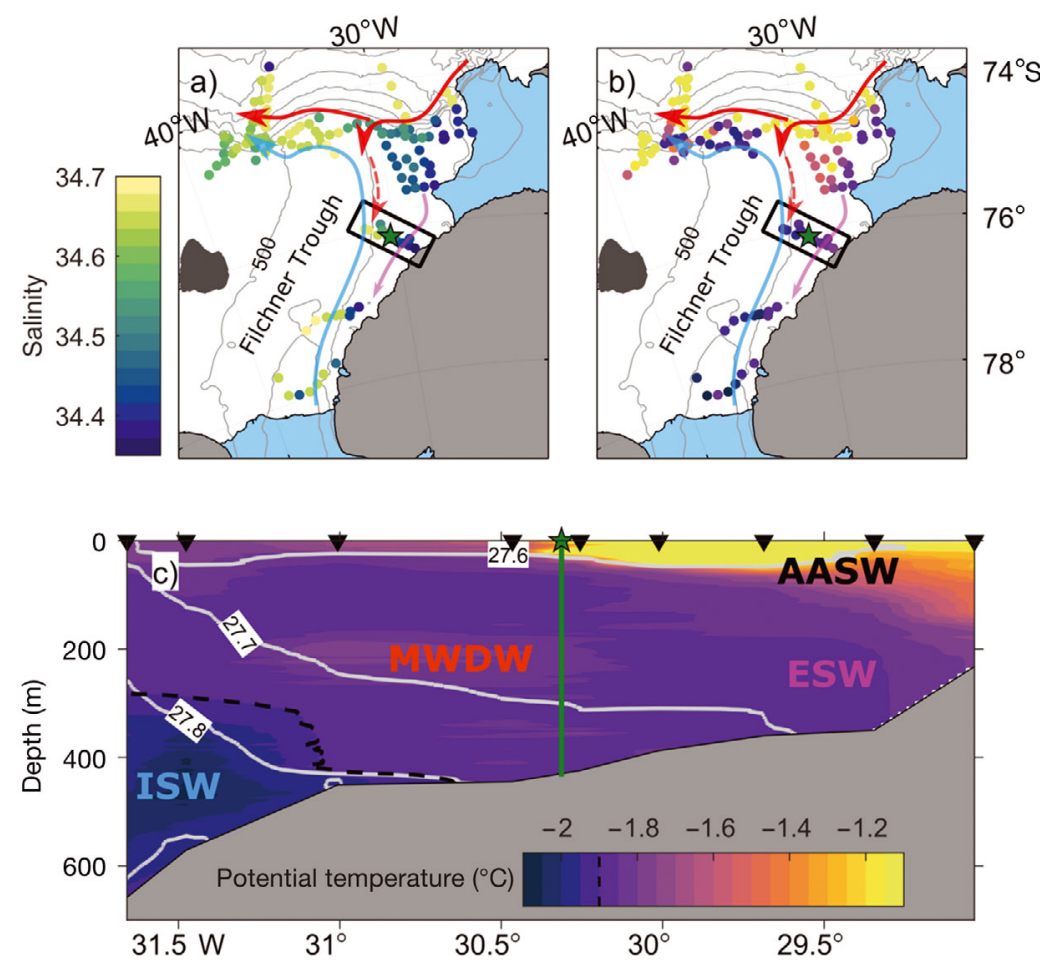

Fig. 3. (a) Bottom salinity and (b) bottom potential temperature of the southern Weddell Sea. Solid orange arrows: Antarctic Slope Current; dashed orange arrow: Modified Warm Deep Water (MWDW) incursions; pink arrow: movement of Eastern Shelf Water (ESW) in the Antarctic Coastal Current; blue arrow: Ice Shelf Water (ISW) outflow along the eastern flank of the Filchner Trough. Black rectangle in (a) and (b) indicates the area covered by the section in (c). (c) Potential temperature section along $76^{\circ} \mathrm{S}$ off Coats Land. White isolines: potential density lines referenced to the surface; black dashed line: the $-1.9^{\circ} \mathrm{C}$ isotherm to visualize the ISW layer $\left(\theta<-1.9^{\circ} \mathrm{C}\right)$. Potential temperature scale in (c) is the same used in (b). Green vertical line and green star in (a), (b), and (c): location of Stn 39. AASW: Antarctic Surface Water 
$351 \mathrm{~m}$ along the narrow shelf characteristic of the eastern Weddell Sea, where the AACC merges with the ASC. The corresponding CTD data showed the presence of fresh ESW throughout the water column, resembling a typical summer shelf profile with a warm, fresh surface layer. No intrusions of MWDW were observed (Fig. 4).

At the stations east of the Filchner Trough, salinities were generally higher (Fig. 4). In Halley Bay, a more saline water column was observed, with no evidence of MWDW (Fig. 4). Increased temperature in the surface layer with no associated reduction in salinity was consistent with sampling in the summer polynya, caused by off-shore winds pushing the ice away from the coast. CTD data from the transect at $76^{\circ} \mathrm{S}$ off Coats Land described by Ryan et al. (2017) (Fig. 3c) captured the warm inflow of MWDW along the eastern flank of the Filchner Trough. In the bottom layer, where the sample of silverfish was taken at a depth of $450 \mathrm{~m}$, a small decrease in temperature and increase in salinity suggested proximity to the ISW layer reaching over the shelf from the flank of the Filchner Trough (Fig. 4). In the surface layer, decreased salinity and increased temperature indicated Antarctic Surface Water (AASW), derived from melting sea ice (Figs. 3c \& 4). At the $77^{\circ} \mathrm{S}$ section just east of the trough flank, the surface layer is again occupied by AASW, as well as a solid layer of ESW to $360 \mathrm{~m}$ over the eastern shelf (Fig. 4). However, fish were sampled further offshore and deeper, along the 450 and $700 \mathrm{~m}$ bottom contours, exposed to ISW flowing north along the eastern flank of the trough (Fig. 4).
At the section across the shelf-break west of the Filchner Trough mouth, fish were sampled where warm, saline water characterized by a reduction in oxygen indicated MWDW occupying the bottom layer (WF in Fig. 4). The MWDW was part of the western incursion described by Schröder et al. (2014), facilitated by isopycnal lifting due to the dense Filchner outflow (Nicholls et al. 2009), forming a direct pathway onto the continental shelf. Some freshening near the surface, without an associated increase in temperature, showed again the influence of summer sea ice melting.

\subsection{Biological data: spatial length distributions and nucleus chemistry}

Stations where adult silverfish were most abundant coincided with the presence of MWDW intrusions observed over the shelf east (Table 1, Fig. S1a in the Supplement at www.int-res.com/articles/suppl/ m624p195_supp.pdf; Stns 166, 306, 282, and 129) of the trough mouth, in the trough mouth (Stn 188), and over the shelf west (Stn 248) of the trough mouth (Wetjen et al. 2014a). By comparison, abundance indices were much lower further south over the eastern shelf adjoining the Filchner Trough, and along the shelf-break (Fig. S1a; Stns 331, 316, 11, 175, 201, and 249).

Abundance and biomass indices showed evidence of spatial decoupling related to differences in the distribution of fish from the large and small modes in the length distribution (Fig. 5). Mature, large mode fish were found throughout the region around
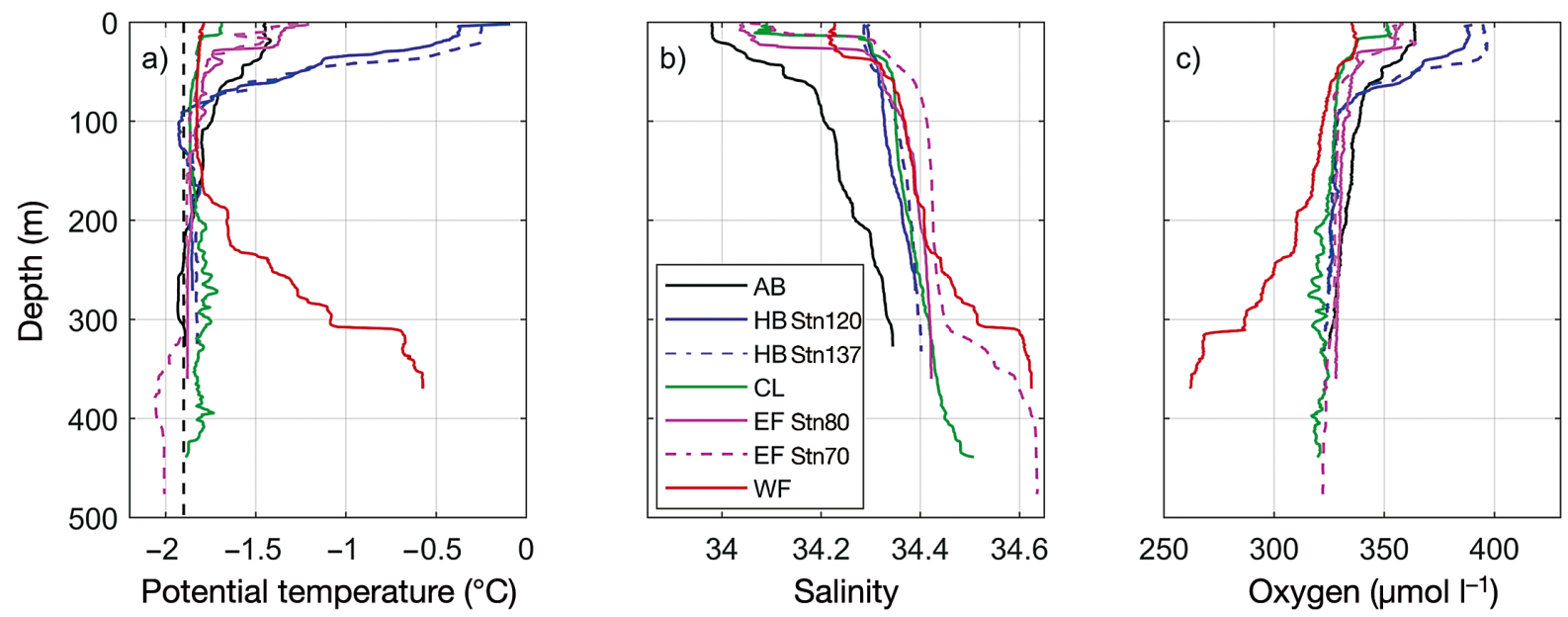

Fig. 4. CTD profiles from the Weddell Sea showing (a) potential temperature, (b) salinity, and (c) dissolved oxygen. Plots correspond to data from Atka Bay (AB), Halley Bay (HB), Coats Land (CL), east Filchner Trough (EF), and west Filchner Trough (WF) 

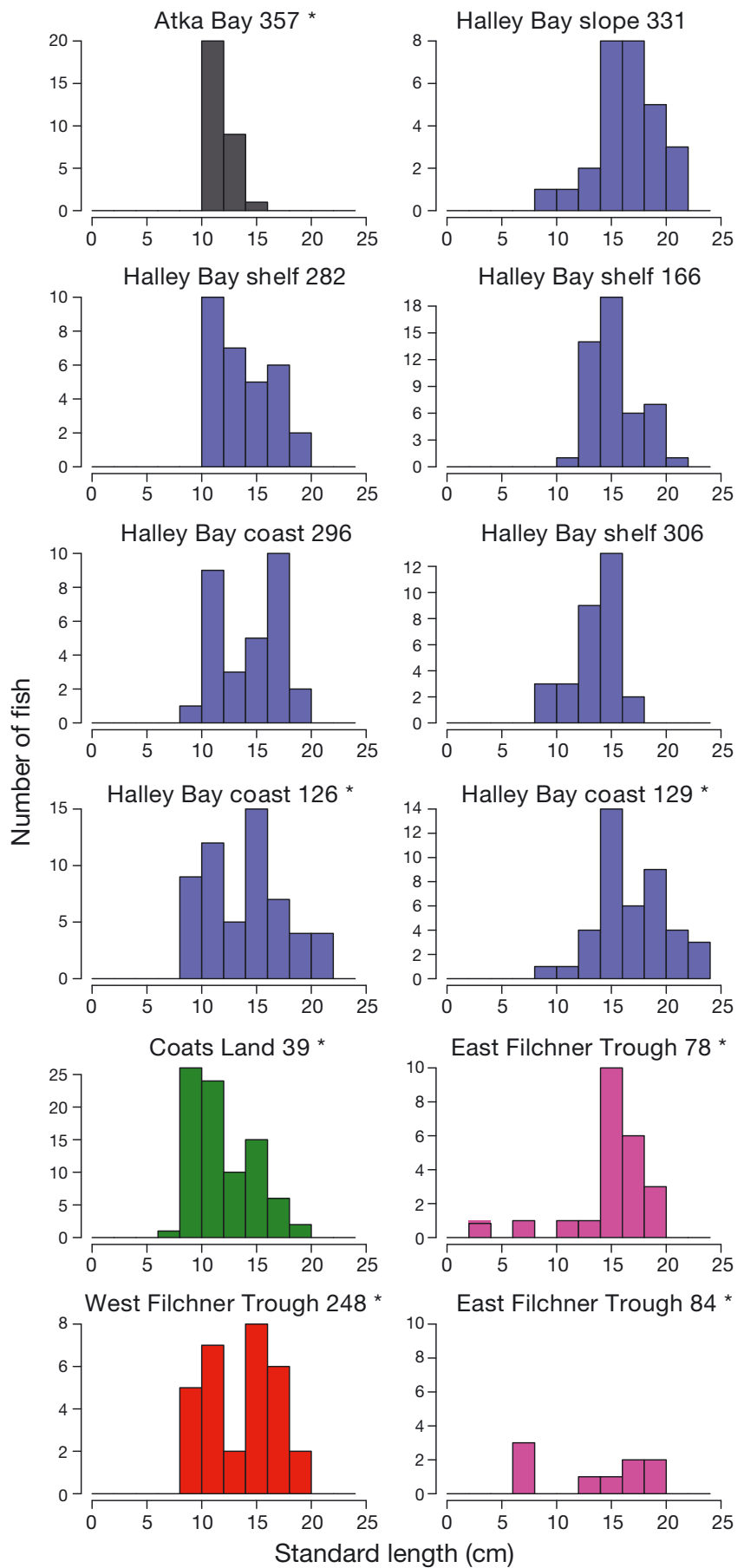

Fig. 5. Standard length distributions of Pleuragramma antarctica in the Weddell Sea. Sampling areas and station numbers are specified above the graphs. Asterisks $\left({ }^{*}\right)$ indicate stations sub-sampled for otolith chemistry. Left column highlights bimodal stations (with the exception of Atka Bay); right column highlights unimodal stations

the Filchner Trough, including hauls along the section at $77^{\circ} \mathrm{S}$ just east of the trough flank and the northeastern part of Halley Bay, but not further east where only 3 fish were caught off Camp Nor- way, and in Atka Bay where primarily immature fish were found. The intrusions of MWDW along the eastern shelf were associated with small mode fish at Stns 282, 296, 126, and 39. However, small mode fish were not caught in hauls along the $77^{\circ} \mathrm{S}$ section just east of the trough flank or in northeastern Halley Bay.

Compared to the genetic analysis, in which no spatial differences in gene frequencies were found (Caccavo et al. 2018), the chemistry in the otolith nuclei showed significant differentiation (multivariate ANOVA Pillai's trace; $F_{21,492}=3.36, \mathrm{p}<0.0001$; Table 3a), consistent with spatial structuring. All MANOVA contrasts were significant (experiment-wise $\alpha=0.05$ ): strong contrast between large and small length modes (Pillai's trace; $F_{1,3}=6.18, \mathrm{p}=0.0005$ ) indicated immature and mature fish were exposed to different environments during early life; differences between Atka Bay and Halley Bay (multivariate ANOVA Pillai's trace; $\left.F_{1,3}=11.94, \mathrm{p}<0.0001\right)$, and Halley Bay and Filchner Trough (Pillai's trace; $F_{1,3}=4.66, \mathrm{p}=0.0038$ ) suggested spatial structuring along the continental shelf. The distribution of variates along the first canonical variable (Fig. 6) reflected the differences between large and small mode fish, between Atka Bay and Halley Bay, and between Halley Bay and Filchner Trough. Offsets were notable particularly between Atka Bay and both large and small mode fish in Halley Bay.

Examining univariate data for adults, differences in otolith nucleus chemistry between areas were primarily due to $\mathrm{Mg}: \mathrm{Ca}$ (Table $3 \mathrm{~b}$ ), which showed strong differences for all 3 contrasts. Sr:Ca showed a significant difference between large and small mode fish, but not between Atka Bay, Halley Bay, and Filchner Trough. Ba:Ca showed no significant differences for any of the contrasts. The Scheffé test for $\mathrm{Mg}: \mathrm{Ca}$ indicated ordering in the treatments: $\mathrm{AB}$ differed significantly from HB-L and EF-L, but was similar to WF-S and CL-S. For Sr:Ca, treatments were ordered according to mode, with $\mathrm{AB}$ most similar to CL-S, HB-S, and WF-S. Similarly, ordering by Ba:Ca showed CL-S to be most similar to HB-S and AB. These results suggested similarities in environmental exposures during early life between immature fish in Atka Bay and those in Halley Bay and Filchner Trough, with greater differentiation from large mode fish. Nevertheless, significant differences between Atka Bay and Halley Bay, and Halley Bay and Filchner Trough indicated spatial structuring in nucleus chemistry related to water mass properties and circulation over the continental shelf of the southern Weddell Sea. 
Table 3. (a) Multivariate and (b) univariate analyses of variance (MANOVA, ANOVA) for otolith nuclei of Pleuragramma antarctica; F- and p-values shown. ANOVA testing for difference in concentrations of $\mathrm{Mg}: \mathrm{Ca}, \mathrm{Ba}: \mathrm{Ca}$, and $\mathrm{Sr}: \mathrm{Ca}$. Asterisks ( ${ }^{*}$ ) indicate significance at experiment-wise $\alpha=0.05$

\begin{tabular}{|c|c|c|c|c|c|c|}
\hline $\begin{array}{l}\text { a) MANOVA } \\
\text { Pillai's Trace }\end{array}$ & $F$-value & $\mathrm{p}$ & & & & \\
\hline $\mathrm{H}_{0}$ : No treatment effect & 3.36 & $<0.0001$ & & & & \\
\hline $\mathrm{C}_{1}$ : Atka Bay and Halley Bay & 11.94 & $<0.0001$ & & & & \\
\hline $\mathrm{C}_{2}$ : Halley Bay and Filchner Trough & 4.66 & 0.0038 & & & & \\
\hline $\mathrm{C}_{3}$ : Small $(<13 \mathrm{~cm})$ and large $(\geq 13 \mathrm{~cm})$ & 6.18 & 0.0005 & & & & \\
\hline \multicolumn{7}{|l|}{ b) ANOVA } \\
\hline Contrast & $\mathrm{Mg}: \mathrm{Ca}$ & $\begin{array}{c}-F \text {-value } \\
\text { Sr:Ca }\end{array}$ & $\mathrm{Ba}: \mathrm{Ca}$ & $\mathrm{Mg}: \mathrm{Ca}$ & $\overline{\mathrm{Sr}} \mathrm{p}-\mathrm{Ca}$ & $\mathrm{Ba}: \mathrm{Ca}$ \\
\hline Atka Bay and Halley Bay & 32.73 & 2.22 & 0.03 & $<0.0001^{*}$ & 0.1380 & 0.8610 \\
\hline Halley Bay and Filchner Trough & 9.90 & 0.26 & 0.99 & $0.0020^{*}$ & 0.6090 & 0.3220 \\
\hline Small $(<13 \mathrm{~cm})$ and large $(\geq 13 \mathrm{~cm})$ & 8.94 & 11.03 & 2.54 & $0.0032^{*}$ & $0.0010^{*}$ & 0.1130 \\
\hline
\end{tabular}

\section{DISCUSSION}

\subsection{Spatial structure and connectivity in the southern Weddell Sea}

Our results illustrate the advantages of multidisciplinary approaches (Begg et al. 1999, Sturrock et al. 2012) for addressing population structure in Antarctic fish. Even though Caccavo et al. (2018) found no evidence of genetic differentiation among silverfish, the chemistry in otolith nuclei indicated significant spatial structuring along the south Weddell Sea continental shelf. Mediated by physiological processes that are associated with changes in water properties in the Southern Ocean (Ashford et al. 2005, 2006), $\mathrm{Mg}: \mathrm{Ca}$ and $\mathrm{Sr}: \mathrm{Ca}$ differentiated modes that recurred in the length distributions, and Mg:Ca detected significant differences between Atka Bay, Halley Bay, and Filchner Trough. Sampling as part of a hydrographic survey linked comparisons to the circulation and hydrography. This provided valuable physical context to help unravel the physical-biological interactions that potentially underlie population structure and connectivity, and resolve the information provided by the complementary techniques.

Considering the nucleus chemistry further, it integrated material laid down over the first summer of growth, during which fish are thought to remain within the circulation associated with their natal trough (Brooks et al. 2018). Silverfish show considerable consistency in reproductive timing and behavior: despite substantial variation in environmental conditions, hatching occurs between December and January (La Mesa et al. 2015b). Larvae are subsequently entrained in trough circulation and advected in
AASW in the surface layer. This layer varies with surface heating, freshwater inputs, and mixing with neighboring water masses, shaping the environments that larvae are exposed to. Wind fields, sea ice distributions, melt from sea ice and nearby glaciers, as well as surface air temperatures and solar radiation are all likely to generate differences in nucleus chemistry between troughs that can form reliable evidence of population separation.

However, this study highlights several concerns. Firstly, physical conditions vary over time as well, and differences in nucleus chemistry such as we found between length modes may simply reflect variation on inter-annual time scales within a single natal trough. Secondly, variation within troughs might generate differences between larvae advected to the ASC in the outflow and those retained through mixing with the inflow. For instance, differences in temperature might be expected to affect growth and hence $\mathrm{Sr}: \mathrm{Ca}$, while differences in turbulence and flow might affect activity and hence $\mathrm{Mg}: \mathrm{Ca}$. A third concern relates to the narrow shelf in the eastern Weddell Sea: short trough configurations might lead to earlier exposures to the slope front in larvae entering the ASC. Again, differences in temperature exposure and activity in the ASC might generate differences in nucleus chemistry compared to fish from the same population that remained in the trough circulation.

A full account of the spatial component of variation can help quantify these effects on the nucleus chemistry and resolve the similarities we found between Atka Bay and small mode fish downstream. Contrasts between Atka Bay, Halley Bay, and Filchner Trough indicated structuring, as well as the distributions of the canonical variates particularly between Atka Bay 


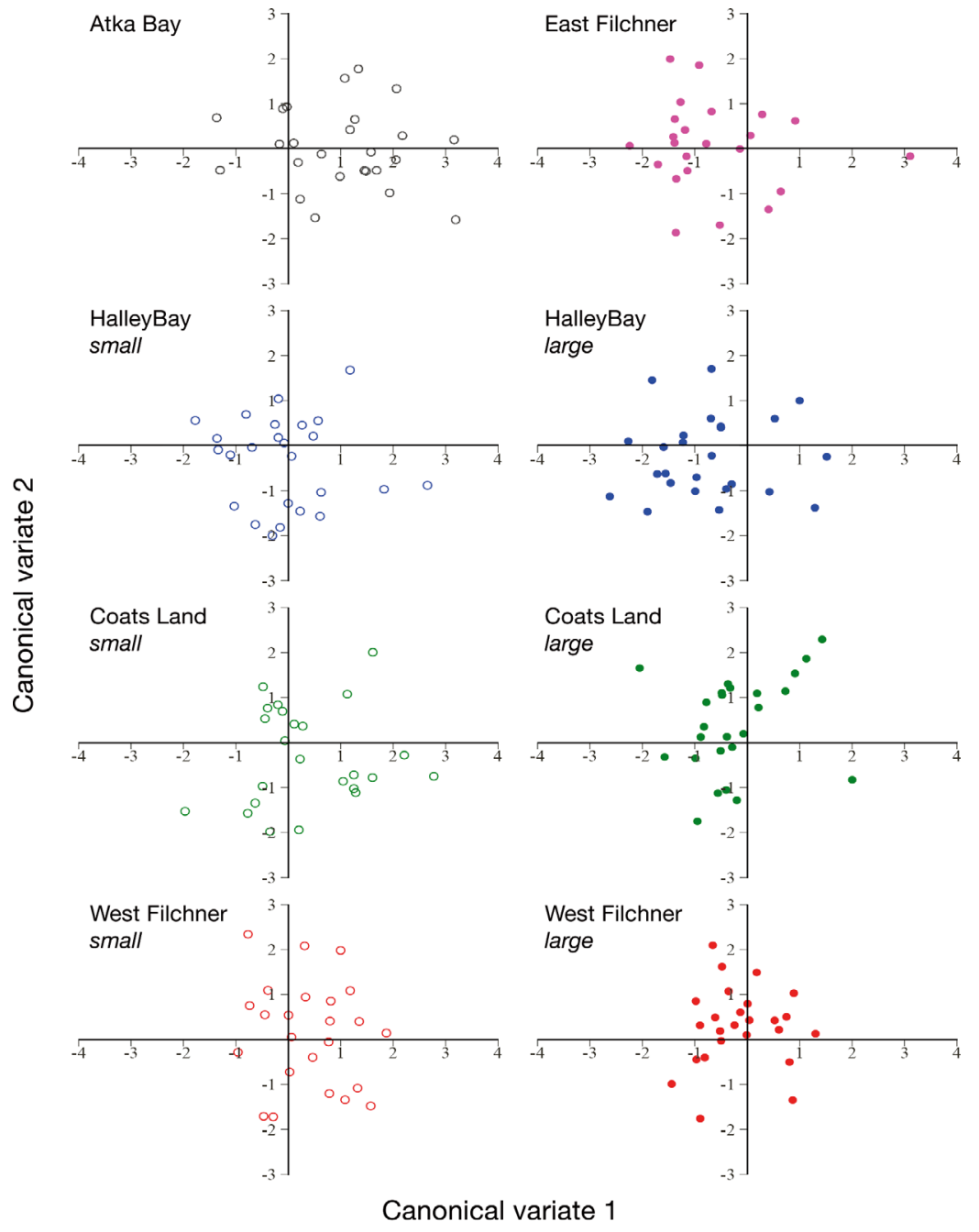

Fig. 6. Relationships between Pleuragramma antarctica from the different treatment groups using canonical discriminant variates based on otolith nucleus chemistry. Open circles: treatment groups composed of small fish; filled circles: treatment groups consisting of large fish

and Halley Bay. Yet length distributions and pairwise comparisons in univariate markers showed similarities between fish from Atka Bay and small mode fish in Halley Bay and Filchner Trough. If small mode fish were advected along the shelf, trough configurations in the eastern Weddell Sea might be sufficiently short that they incorporated material in their nuclei after entering the ASC. Variation within the trough circulation and between years might also contribute to the differences we found between areas and between modes. Notably however, few small mode fish were found in northeastern Halley Bay, where fresher water from the eastern continental shelf flows inshore along the $400 \mathrm{~m}$ isobath (Nicholls et al. 2009). Instead, length, abundance, and biomass indices all showed strong spatial association between small mode fish and MWDW along the shelf-break and intruding along the eastern flank of Filchner Trough. In contrast to White \& Piatkowski (1993), this suggests that fish would have arrived along the ASC in deeper water following ontogenetic movement to depth.

Large mode fish, on the other hand, occurred in northeastern Halley Bay as well as all samples around Filchner Trough. They accounted for high abundance indices associated with incursions of MWDW east of the Filchner Sill. They were also found in association with small mode fish along the Filchner Trough and western shelf-break close to the interface between ISW and MWDW, an interface characterized by turbulence and mixing (Fer et al. 2016). Provenance from areas upstream would be consistent with the dense aggregations of larvae found by Hubold (1984) off Camp Norway and the evidence supporting larval dispersal reported by White \& Piatkowski (1993). In this scenario, advection in the surface layer would supply northeastern Halley Bay, mediated by ontogenic movement off the Brunt Ice Shelf from the upper water column to deeper ESW off the Brunt Ice Shelf. Young stages continuing in the AACC, or older stages following flow in deeper ESW, penetrate further south along the eastern shelf, accounting for the lower abundance indices encountered there during sampling.

Yet this scenario does not account for structuring in the nucleus chemistry between Halley Bay and Filchner Trough, and lacks corroborating evidence of similar large mode fish in Atka Bay and near the Camp Norway Trough. This absence also argues against supply from areas further upstream: the narrow shelf in this region is characterized by strong wind-driven surface flow toward the coast (Graham et al. 2013), promoting the transport of larvae entrained within it. Sampling effects may be responsible: only one sample was taken in Atka Bay and off Camp Norway, and further sampling may have revealed adult fish. Alternatively, however, Hubold (1984) also found considerable numbers of larvae over the southern Filchner Trough and suggested that the local wind field and circulation structured early life history, connectivity, and retention as 
far north as the slope front. Large aggregations of larvae were also found during the same cruise as our sampling (Fig. S1b) (Auel et al. 2014), suggesting a competing scenario in which a local population supplies adult distributions over the adjoining shelf. In the following section, we build on Hubold's (1984) original insights, integrating recent knowledge available on the physical system in the Filchner Trough, and outlining how physical-biological interactions with circulation and water structure might help underpin dispersal and retention in a local population.

\subsection{Physical-biological interactions and life history closure in the Filchner Trough}

In this scenario, a discrete, self-recruiting population is structured by the trough circulation, constrained by cryopelagic early stages under sea ice near the head of the trough (Ashford et al. 2017, Brooks et al. 2018). Hatching in December and early January under sea ice near the Filchner Ice Shelf is followed by larval dispersal northward in the trough circulation consistent with the distributions found by Hubold (1984) and Auel et al. (2014) (Fig. S1b). ISW fills the trough and northward flow occurs year-round along the trough flank from under the ice shelf. Spawning in the vicinity of the ice shelf during late winter and early summer exposes adults to this flow. Subsequent adult movement northward is consistent with exclusively large mode fish sampled during this study in ISW at $77^{\circ} \mathrm{S}$ just east of the trough flank at $700 \mathrm{~m}$, compared to sharply decreasing numbers at shallower depths over the adjoining shelf. At $76^{\circ} \mathrm{S}$ off Coats Land, however, ISW reaches onto the shelf during autumn and summer (Ryan et al. 2017), and in this study, fish were found at $450 \mathrm{~m}$ near the ISW interface but not further inshore at $250 \mathrm{~m}$. Ryan et al. (2017) describe the seasonal hydrographic cycle on the eastern shelf in 4 phases: during Phase 1 in summer, MWDW from the continental slope intrudes south at mid-depth, potentially exposing fish to southward flow during their diurnal movement. During Phase 2 in autumn (midMarch-July), the MWDW intrusion reaches the bottom and flow in the benthic layer is strongly southward. In Phase 3, the inflow stops, and the remaining MWDW likely mixes away into the water column due to strong surface forcing during winter. Slow, westward flow occurs across the eastern shelf during winter, providing a pathway for adults returning to spawning areas near the head of the trough.

The strong northward outflow of ISW occurs throughout the year along the eastern flank of the trough, and crosses the sill to contribute to deep water formation (Darelius et al. 2014, Ryan et al. 2017). Consequently, older fish remaining in ISW are exposed to water that connects to the continental slope, accounting for large mode fish sampled at the trough mouth and downstream associated with the ASC. The outflow also provides a return pathway to the continental slope for fish transferring from the MWDW intrusions. Physical effects, due to trough configuration and mixing between water masses, potentially interact with biological ones, like diurnal migration through the water column and feeding opportunities along the boundary between the 2 water masses, to determine rates of transfer between the trough outflow and inflow. Those reaching inflowing water over the edge of the adjoining shelf are retained in the population, whereas those remaining over the trough flank eventually encounter the ASC and are advected westward along the continental slope.

Less clear in this scenario is how larvae in the surface layer can reach the eastern shelf. In the Ross Sea, the Drygalski Trough runs parallel with the coast, so that offshore winds generate flows that can enhance mixing across the trough as well as crossshelf advection (Brooks et al. 2018). Near Coulman Island, a potentially important area for larval transfer to the trough inflow (Brooks et al. 2018) is characterized by proximity of the coast on the western side of the trough, a reverse slope, and curvature in the trough configuration. In the Filchner Trough, the reverse slope coincides with curvature and a southwest configuration on the inner shelf; the coast lies parallel on its eastern side, and winds at Halley Bay are predominantly southwestward. As a result, Ekman flows in the surface layer may facilitate advection with a southward component over the eastern shelf.

Moreover, the coastal polynya over the Filchner Trough is narrow, often with proximity of the ice edge to the eastern shelf during summer (Fig. 7). Meltwater from sea ice is an important source of iron to the euphotic zone (McGillicuddy et al. 2015), and the combined effects of the outflow, the location of the ice edge, and the wind field are likely to influence larval growth and survival (Brooks et al. 2018). Thus, when conditions do not coincide at the right time, mortality may be high; or large numbers of larvae are advected to the slope front (as indicated by Hubold 1984), where they are lost to the system. By contrast, much larger proportions retained when conditions coincide may form dominant year classes consistent with the length distributions found by Hubold \& Tomo (1989) and this study. 

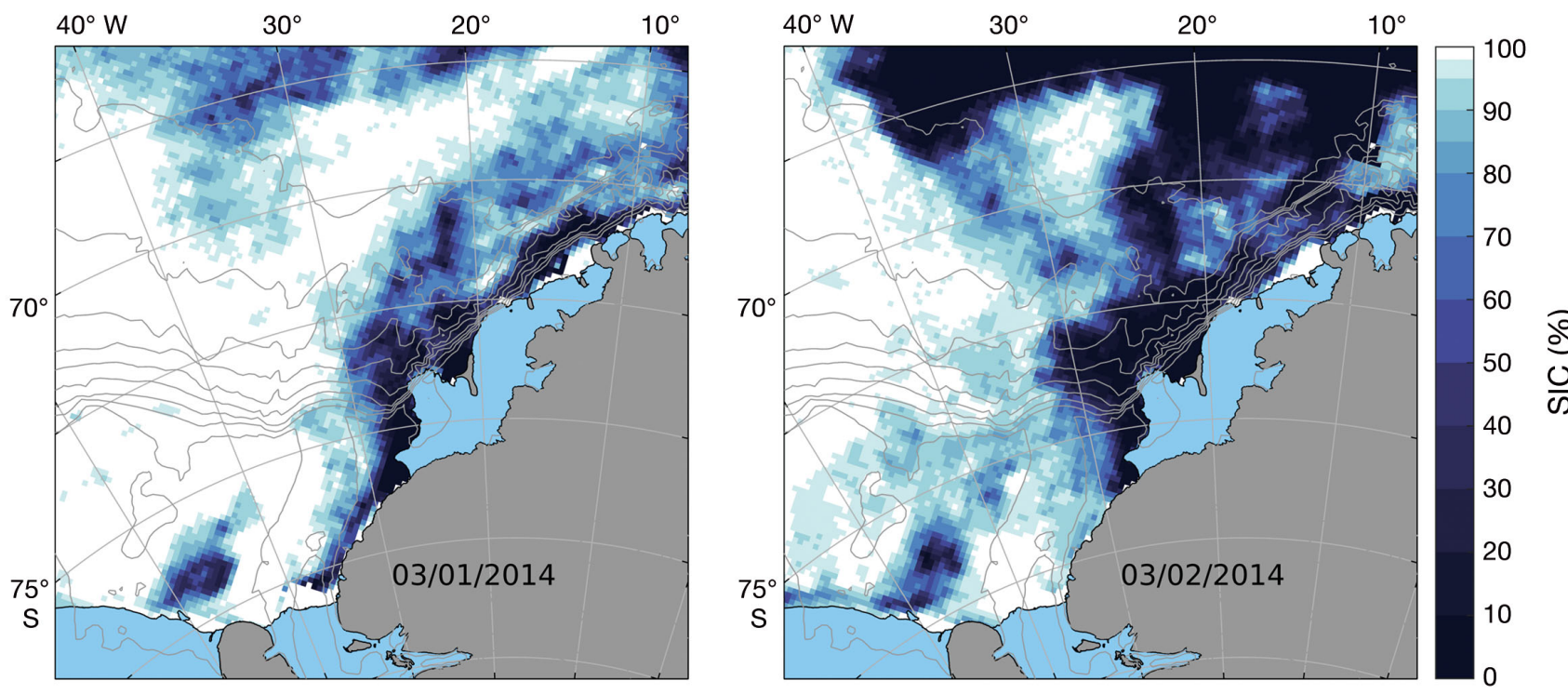

Fig. 7. Sea ice cover in the Weddell Sea in (a) January and (b) February of 2014. SIC: sea ice concentration. Data from http://icdc.cen. uni-hamburg.de/daten/cryosphere/seaiceconcentration-asi-ssmi.html (ftp://ftp-icdc.cen.uni-hamburg.de/asi_ssmi_iceconc/ant)

\subsection{Examining physical-biological hypotheses using a multi-disciplinary approach.}

Multi-disciplinary approaches can promote synergies that ultimately strengthen the understanding of population structure and demography (Welch et al. 2015). Immigration of young stages into Filchner Trough along the AACC, or older stages deeper along intrusions of MWDW from the ASC, can help explain strong gene flow along East Antarctica into the Weddell Sea (Caccavo et al. 2018). Export of larvae along the ASC, or older fish in ISW across the Filchner Sill, are consistent with genetic homogeneity in shelf areas downstream along the ASC. Variability in length distributions on small spatial scales and over time can help explain changes in allele frequencies representative of chaotic genetic patchiness, previously found in silverfish (Zane et al. 2006, Agostini et al. 2015, Caccavo et al. 2018) and more generally attributed to inter-annual variations in recruitment and dispersal (Johnson \& Black 1982). Our results suggest that variability in provenance with length, as indicated by the otolith chemistry, may also play a role.

Such comparisons between techniques can yield further insights. High levels of gene flow argue that a hypothesis of a discrete population associated with Filchner Trough, in which self-recruitment and mortality exclusively determine abundance, remains incomplete: in a discrete population, self-recruitment and mortality exclusively determine abundance, and there is no migration to support gene flow. Moreover, inconsistent with random mixing in a single population, otolith chemistry indicated structure along the adjoining eastern shelf with Halley Bay, even when length distributions were taken into account. Additionally, small numbers of larvae along the shelfbreak east of the Filchner Trough and in Halley Bay (Fig. S1b) (Auel et al. 2014) support continuing larval connectivity in the upper water column along the slope, and the possibility of localized spawning in Halley Bay. Taken together, these results suggest that migrants, at different life stages and following multiple pathways, may join one or more local populations along the southern Weddell Sea continental shelf. Associated with the circulation in the Filchner Trough, abundances may be determined by immigration and emigration as well as self-recruitment and mortality.

Length distributions indicate that these vital rates vary considerably over time, and the hydrography can help to explain the variation. The 4 phases defined by Ryan et al. (2017) described circulation patterns in the southern Weddell Sea following MWDW flow onto the shelf during summer and autumn; surface freezing temperatures and the development of a weakly stratified water column cause a subsequent shift in circulation patterns during winter. However, points of transition between the predominant phases are often characterized by variable flow (October being the month with the highest observed variability in this respect), and seasonal variations in water mass thickness and penetration are likely to con- 
tribute to variability in the strength and direction of the circulation between years. While a consistent feature along the Weddell Sea continental slope, the ASC is sensitive to wind stress forcing on seasonal and inter-annual time scales (Youngs et al. 2015, Meijers et al. 2016, Azaneu et al. 2017) and the AACC also shows increased current speed in response (Daae et al. 2018). Moorings along the eastern flank of the Filchner Trough have suggested considerable inter-annual variation in the amount of MWDW and the distance it penetrates onto the shelf (Darelius et al. 2016, Ryan et al. 2017). As a result, physical-biological interactions with the annual life cycle are likely to generate considerable variation in the composition of year classes.

Mixing between immigrants and locally recruited fish can explain the structuring found in the otolith chemistry, varying in relation to position between the ice shelf, Halley Bay, and the shelf-break. The hydrographic regime, in addition to generally low adult abundances compared to the slope regions, argue that relatively few mature fish contribute disproportionately to spawning along the southern shelf. The high levels of abundance and biomass observed at stations along the slope (Fig. S1a) associated with MWDW may represent attraction to feeding opportunities, and relatively few adults subsequently return to spawning areas at the trough head. Instead, physical-biological interactions with the ASC may result in entrainment and advection downstream.

Further research can address these questions and estimate the relative importance of self-recruitment, mortality, and migration rates in determining silverfish abundance and distribution. Our results illustrate how multi-disciplinary approaches can offer important advantages when used to test spatial predictions based on physical-biological population hypotheses. Otolith stable isotopes also have potential, given the strong effects of latitude on ${ }^{18} \mathrm{O}$ in ambient water in the Antarctic (Ashford \& Jones 2007). The technique does not currently allow fine sampling restricted to the first summer of growth (Ferguson 2012), but remains an ongoing area of interest in our research group. As previously demonstrated by Brooks et al. (2018) in the Ross Sea, sampling targeted by water mass is critical in the southern Weddell Sea to characterize distributions in relation to hydrographic variability. Downstream, similar sampling will be crucial to understand how much the southern Weddell Sea contributes to silverfish aggregations in Larsen Bay and around the tip of the Antarctic Peninsula. Caccavo et al. (2018) have already shown no significant genetic differentiation between fish from the
Weddell Sea, Larsen Bay, and the northern Antarctic Peninsula. Otolith chemistry can help test whether this genetic panmixia is representative of a single population supplying these areas, or smaller coherent populations structured by the local circulation. A similar approach along East Antarctica can throw light on the physical-biological interactions supporting gene flow along the ASC from the Ross Sea. In this way, multi-disciplinary techniques, integrated in sampling designs that incorporate hydrography, can help strengthen our understanding of population structure along the shelf and the spatial scales on which connectivity occurs around the Southern Ocean.

Acknowledgements. We thank Nils Koschnick (Alfred Wegener Institute, AWI) and Emilio Riginella (University of Padua) for their help in collecting samples onboard the RV 'Polarstern'. We thank Mathieu Casado (AWI, Potsdam) for his assistance with several of the figures. Ludovica Dal Borgo and Lisa De Biasio (University of Padua) are thanked for their help in confirming the size of the raster area ablated over the otolith nucleus through detailed microscope images. We thank Mario La Mesa (Institute of Marine Science [ISMAR], Ancona) for his assistance in procuring the photo of Pleuragramma antarctica used in Fig. 1. We are indebted to 4 anonymous reviewers who considerably enhanced the quality of the final version of the manuscript. We acknowledge support from the National Program for Antarctic Research (PNRA) project (PdR 2013_C1.07) to Mario La Mesa which supported Emilio Riginella's participation on the RV 'Polarstern'. This work was supported by the PNRA project (16_307) to L.Z. J.A.C. recently completed her PhD in Evolution, Ecology and Conservation at the University of Padua, with funding from a Cariparo Fellowship for foreign students and additional support from an Antarctic Science International (ASI) Bursary, a Scientific Committee for Antarctic Research (SCAR) Fellowship, and an Erasmus+ Student Traineeship. J.A.C. now acknowledges support from the Alexander von Humboldt Foundation in the form of a Humboldt Research Fellowship for Postdoctoral Researchers funding her current research at AWI and BeGenDiv. C.P. acknowledges financial support from the University of Padua (BIRD164793/ 16) and from the European Marie Curie project 'Polarexpress' Grant No. 622320. Funding for J.R.A. was provided by the National Science Foundation (Grant No. 0741348).

\section{LITERATURE CITED}

Agostini C, Patarnello T, Ashford JR, Torres JJ, Zane L, Papetti C (2015) Genetic differentiation in the ice-dependent fish Pleuragramma antarctica along the Antarctic Peninsula. J Biogeogr 42:1103-1113

Årthun M, Nicholls KW, Makinson K, Fedak MA, Boehme L (2012) Seasonal inflow of warm water onto the southern Weddell Sea continental shelf, Antarctica. Geophys Res Lett 39:L17601

Ashford J, Jones C (2007) Oxygen and carbon stable isotopes in otoliths record spatial isolation of Patagonian toothfish (Dissostichus eleginoides). Geochim Cosmochim Acta 71:87-94 
Ashford JR, Jones CM, Hofmann E, Everson I, Moreno C, Duhamel G, Williams R (2005) Can otolith elemental signatures record the capture site of Patagonian toothfish (Dissostichus eleginoides), a fully marine fish in the Southern Ocean? Can J Fish Aquat Sci 62:2832-2840

Ashford JR, Arkhipkin AI, Jones CM (2006) Can the chemistry of otolith nuclei determine population structure of Patagonian toothfish Dissostichus eleginoides? J Fish Biol 69:708-721

Ashford JR, Arkhipkin AI, Jones CM (2007) Otolith chemistry reflects frontal systems in the Antarctic Circumpolar Current. Mar Ecol Prog Ser 351:249-260

Ashford JR, Jones CM, Hofmann EE, Everson I, Moreno CA, Duhamel G, Williams R (2008) Otolith chemistry indicates population structuring by the Antarctic Circumpolar Current. Can J Fish Aquat Sci 65:135-146

* Ashford J, La Mesa M, Fach BA, Jones C, Everson I (2010) Testing early life connectivity using otolith chemistry and particle-tracking simulations. Can J Fish Aquat Sci 67:1303-1315

Ashford J, Dinniman M, Brooks C, Andrews AH and others (2012) Does large-scale ocean circulation structure life history connectivity in Antarctic toothfish (Dissostichus mawsoni)? Can J Fish Aquat Sci 69:1903-1919

Ashford J, Zane L, Torres JJ, La Mesa M, Simms AR (2017) Population structure and life history connectivity of Antarctic silverfish (Pleuragramma antarctica) in the Southern Ocean ecosystem. In: Vacchi M, Pisano E, Ghigliotti L (eds) The Antarctic silverfish: a keystone species in a changing ecosystem. Springer International Publishing, Cham, p 193-234

Auel H, Dürschlag J, Dieter J, Ksionzek K and others (2014) Biological and biogeochemical processes in sea ice and the pelagic realm. In: Knust R, Schröder A (eds) The expedition PS82 of the Research Vessel Polarstern to the southern Weddell Sea in 2013/2014. Reports on Polar and Marine Research, Vol 680. Alfred Wegener Institute, Bremerhaven, p 54-60

Azaneu M, Heywood KJ, Queste BY, Thompson AF (2017) Variability of the Antarctic Slope Current system in the northwestern Weddell Sea. J Phys Oceanogr 47:2977-2997

Begg GA, Friedland KD, Pearce JB (1999) Stock identification and its role in stock assessment and fisheries management: an overview. Fish Res 43:1-8

* Brooks CM, Caccavo JA, Ashford J, Dunbar R, Goetz K, La Mesa M, Zane L (2018) Early life history connectivity of Antarctic silverfish (Pleuragramma antarctica) in the Ross Sea. Fish Oceanogr 27:274-287

Caccavo JA, Papetti C, Wetjen M, Knust R, Ashford JR, Zane L (2018) Along-shelf connectivity and circumpolar gene flow in Antarctic silverfish (Pleuragramma antarctica). Sci Rep 8:17856

* Campana SE (1999) Chemistry and composition of fish otoliths: pathways, mechanisms and applications. Mar Ecol Prog Ser 188:263-297

* Campana SE, Fowler AJ, Jones CM (1994) Otolith elemental fingerprinting for stock identification of Atlantic cod (Gadus morhua) using laser ablation ICPMS. Can J Fish Aquat Sci 51:1942-1950

* Chen Z, Canil D, Longerich HP (2000) Automated in situ trace element analysis of silicate materials by laser ablation inductively coupled plasma mass spectrometry. Fresenius J Anal Chem 368:73-78

* Daae K, Darelius E, Fer I, Østerhus S, Ryan S (2018) Wind stress mediated variability of the Filchner Trough overflow,
Weddell Sea. J Geophys Res Oceans 123:3186-3203

*Darelius E, Makinson K, Daae K, Fer I, Holland PR, Nicholls KW (2014) Hydrography and circulation in the Filchner Depression, Weddell Sea, Antarctica. J Geophys Res Oceans 119:5797-5814

Warelius E, Fer I, Nicholls KW (2016) Observed vulnerability of Filchner-Ronne Ice Shelf to wind-driven inflow of warm deep water. Nat Commun 7:12300

* Davis LB, Hofmann EE, Klinck JM, Piñones A, Dinniman MS (2017) Distributions of krill and Antarctic silverfish and correlations with environmental variables in the western Ross Sea, Antarctica. Mar Ecol Prog Ser 584:45-65

* Dehairs F, Baeyens W, Goeyens L (1992) Accumulation of suspended barite at mesopelagic depths and export production in the Southern Ocean. Science 258:1332-1335

Duhamel G, Hulley PA, Causse R, Koubbi P and others (2014) Biogeographic patterns of fish. In: De Broyer C, Koubbi P, Griffiths HJ, Raymond B and others (eds) Biogeographic atlas of the Southern Ocean. Scientific Committee on Antarctic Research, Cambridge, p 328-362

* Dutrieux P, De Rydt J, Jenkins A, Holland PR and others (2014) Strong sensitivity of Pine Island ice-shelf melting to climatic variability. Science 343:174-178

*Eastman JT, DeVries AL (1989) Ultrastructure of the lipid sac wall in the Antarctic notothenioid fish Pleuragramma antarcticum. Polar Biol 9:333-335

*Fer I, Darelius E, Daae KB (2016) Observations of energetic turbulence on the Weddell Sea continental slope. Geophys Res Lett 43:760-766

Ferguson JW (2012) Population structure and connectivity of an important pelagic forage fish in the Antarctic ecosystem, Pleuragramma antarcticum, in relation to large scale circulation. MSc thesis, Old Dominion University, Norfolk, VA

Ghigliotti L, Herasymchuk VV, Kock KH, Vacchi M (2017) Reproductive strategies of the Antarctic silverfish: known knowns, known unknowns and unknown unknowns. In: Vacchi M, Pisano E, Ghigliotti L (eds) The Antarctic silverfish: a keystone species in a changing ecosystem. Springer International Publishing, Cham, p 173-192

* Graham JA, Heywood KJ, Chavanne CP, Holland PR (2013) Seasonal variability of water masses and transport on the Antarctic continental shelf and slope in the southeastern Weddell Sea. J Geophys Res Oceans 118:2201-2214

*Guglielmo L, Granata A, Greco S (1997) Distribution and abundance of postlarval and juvenile Pleuragramma antarcticum (Pisces, Nototheniidae) off Terra Nova Bay (Ross Sea, Antarctica). Polar Biol 19:37-51

Guidetti P, Ghigliotti L, Vacchi M (2015) Insights into spatial distribution patterns of early stages of the Antarctic silverfish, Pleuragramma antarctica, in the platelet ice of Terra Nova Bay, Antarctica. Polar Biol 38:333-342

Heywood KJ, Locarnini RA, Frew RD, Dennis PF, King BA (1998) Transport and water masses of the Antarctic Slope Front system in the eastern Weddell Sea. In: Jacobs SS, Weiss RF (eds) Ocean, ice, and atmosphere: interactions at the Antarctic continental margin. Antarctic Research Series, Vol 75. American Geophysical Union, Washington, DC, p 203-214

Hubold G (1984) Spatial distribution of Pleuragramma antarcticum (Pisces: Nototheniidae) near the Filchnerand Larsen ice shelves (Weddell Sea/Antarctica). Polar Biol 3:231-236

*Hubold G, Tomo AP (1989) Age and growth of Antarctic silverfish Pleuragramma antarcticum Boulenger, 1902, from 
the southern Weddell Sea and Antarctic Peninsula. Polar Biol 9:205-212

Jochum KP, Scholz D, Stoll B, Weis U and others (2012) Accurate trace element analysis of speleothems and biogenic calcium carbonates by LA-ICP-MS. Chem Geol 318-319:31-44

Johnson MS, Black R (1982) Chaotic genetic patchiness in an intertidal limpet, Siphonaria sp. Mar Biol 70:157-164

Kellermann A (1986) Geographical distribution and abundance of postlarval and juvenile Pleuragramma antarcticum (Pisces, Notothenioidei) off the Antarctic Peninsula. Polar Biol 6:111-119

Kellermann AK (1996) Midwater fish ecology. In: Ross RM, Hofmann EE, Quetin LB (eds) Foundations for ecological research west of the Antarctic Peninsula, Vol 70. American Geophysical Union, Washington, DC, p 231-256

Khattree R, Naik DN (1999) Applied multivariate statistics with SAS software. SAS Publishing, Cary, NC

Khattree R, Naik DN (2000) Multivariate data reduction and discrimination with SAS software. SAS Publishing, Cary, NC

Knust R, Schröder M (eds) (2014) The expedition PS82 of the Research Vessel Polarstern to the southern Weddell Sea in 2013/2014. Reports on Polar and Marine Research, Vol 680. Alfred Wegener Institute, Bremerhaven

Koubbi P, O'Brien C, Loots C, Giraldo C and others (2011) Spatial distribution and inter-annual variations in the size frequency distribution and abundances of Pleuragramma antarcticum larvae in the Dumont d'Urville Sea from 2004 to 2010. Polar Sci 5:225-238

Koubbi P, Grant S, Ramm D, Vacchi M, Ghigliotti L, Pisano E (2017) Conservation and management of Antarctic silverfish Pleuragramma antarctica populations and habitats. In: Vacchi M, Pisano E, Ghigliotti L (eds) The Antarctic silverfish: a keystone species in a changing ecosystem. Springer International Publishing, Cham, p 287-305

La Mesa M, Eastman JT (2012) Antarctic silverfish: life strategies of a key species in the high-Antarctic ecosystem. Fish Fish 13:241-266

Ka Mesa M, Catalano B, Russo A, Greco S, Vacchi M, Azzali M (2010) Influence of environmental conditions on spatial distribution and abundance of early life stages of Antarctic silverfish, Pleuragramma antarcticum (Nototheniidae), in the Ross Sea. Antarct Sci 22:243-254

La Mesa M, Piñones A, Catalano B, Ashford J (2015a) Predicting early life connectivity of Antarctic silverfish, an important forage species along the Antarctic Peninsula. Fish Oceanogr 24:150-161

La Mesa M, Riginella E, Mazzoldi C, Ashford J (2015b) Reproductive resilience of ice-dependent Antarctic silverfish in a rapidly changing system along the Western Antarctic Peninsula. Mar Ecol 36:235-245

* Lancraft TM, Reisenbichler KR, Robison BH, Hopkins TL, Torres JJ (2004) A krill-dominated micronekton and macrozooplankton community in Croker Passage, Antarctica with an estimate of fish predation. Deep Sea Res II 51:2247-2260

Lowe WH, Allendorf FW (2010) What can genetics tell us about population connectivity? Mol Ecol 19:3038-3051

Matsuoka K, Skoglund A, Roth G (2018) Quantarctica: a free GIS package for Antarctica [Data set]. Norwegian Polar Institute, Tromsø. https://doi.org/10.21334/npolar.2018. $8516 \mathrm{e} 961$

McGillicuddy DJ Jr, Sedwick PN, Dinniman MS, Arrigo KR and others (2015) Iron supply and demand in an Antarctic shelf ecosystem. Geophys Res Lett 42:8088-8097
Meijers AJS, Meredith MP, Abrahamsen EP, Morales Maqueda MA, Jones DC, Naveira Garabato AC (2016) Wind-driven export of Weddell Sea slope water. J Geophys Res Oceans 121:7530-7546

*Moffat C, Beardsley RC, Owens B, van Lipzig N (2008) A first description of the Antarctic Peninsula Coastal Current. Deep Sea Res II 55:277-293

Nicholls KW, Østerhus S, Makinson K, Gammelsrød T, Fahrbach E (2009) Ice-ocean processes over the continental shelf of the southern Weddell Sea, Antarctica: a review. Rev Geophys 47:RG3003

* Orsi AH, Whitworth T III, Nowlin WD Jr (1995) On the meridional extent and fronts of the Antarctic Circumpolar Current. Deep Sea Res I 42:641-673

* Palsbøll PJ, Bérubé M, Allendorf FW (2007) Identification of management units using population genetic data. Trends Ecol Evol 22:11-16

* Parker ML, Fraser WR, Ashford J, Patarnello T, Zane L, Torres JJ (2015) Assemblages of micronektonic fishes and invertebrates in a gradient of regional warming along the Western Antarctic Peninsula. J Mar Syst 152:18-41

Piepenburg D (2016) Seabed photographs taken along OFOS profile PS96/090-4 during POLARSTERN cruise PS96. Alfred Wegener Institute, Helmholtz Center for Polar and Marine Research, Bremerhaven

* Piñones A, Hofmann EE, Dinniman MS, Klinck JM (2011) Lagrangian simulation of transport pathways and residence times along the western Antarctic Peninsula. Deep Sea Res II 58:1524-1539

QGIS Development Team (2018) QGIS geographic information system. Open Source Geospatial Foundation Project. https://qgis.org/en/site/index.html

* Ryan S, Schröder M, Huhn O, Timmermann R (2016) On the warm inflow at the eastern boundary of the Weddell Gyre. Deep Sea Res I 107:70-81

* Ryan S, Hattermann T, Darelius E, Schröder M (2017) Seasonal cycle of hydrography on the eastern shelf of the Filchner Trough, Weddell Sea, Antarctica. J Geophys Res Oceans 122:6437-6453

* Savidge DK, Amft JA (2009) Circulation on the West Antarctic Peninsula derived from 6 years of shipboard ADCP transects. Deep Sea Res I 56:1633-1655

Schröder M, Wisotzki A, Ryan S, Huneke W and others (2014) Observations of the hydrographic conditions and water mass compositions at the Filchner Sill and in the Filchner Trough. In: Knust R, Schröder A (eds) The expedition PS82 of the Research Vessel Polarstern to the southern Weddell Sea in 2013/2014. Reports on Polar and Marine Research, Vol 680. Alfred Wegener Institute, Bremerhaven, p 18-38

* Shaw PW, Arkhipkin AI, Al-Khairulla H (2004) Genetic structuring of Patagonian toothfish populations in the Southwest Atlantic Ocean: the effect of the Antarctic Polar Front and deep-water troughs as barriers to genetic exchange. Mol Ecol 13:3293-3303

Sturrock AM, Trueman CN, Darnaude AM, Hunter E (2012) Can otolith elemental chemistry retrospectively track migrations in fully marine fishes? J Fish Biol 81:766-795

Taillebois L, Barton DP, Crook DA, Saunders T and others (2017) Strong population structure deduced from genetics, otolith chemistry and parasite abundances explains vulnerability to localized fishery collapse in a large sciaenid fish, Protonibea diacanthus. Evol Appl 10:978-993

* Thompson AF, Heywood KJ, Thorpe SE, Renner AHH, 
Trasviña A (2009) Surface circulation at the tip of the Antarctic Peninsula from drifters. J Phys Oceanogr 39:3-26

Thompson AF, Stewart AL, Spence P, Heywood KJ (2018) The Antarctic Slope Current in a changing climate. Rev Geophys 56:741-770

Thorrold SR, Swearer SE (2009) Otolith chemistry. In: Green BS, Mapstone BD, Carlos G, Begg GA (eds) Tropical fish otoliths: information for assessment, management and ecology. Springer Netherlands, Dordrecht, p 249-295

Vacchi M, La Mesa M, Dalu M, MacDonald J (2004) Early life stages in the life cycle of Antarctic silverfish, Pleuragramma antarcticum in Terra Nova Bay, Ross Sea. Antarct Sci 16:299-305

Welch DJ, Newman SJ, Buckworth RC, Ovenden JR and others (2015) Integrating different approaches in the definition of biological stocks: a northern Australian multijurisdictional fisheries example using grey mackerel, Scomberomorus semifasciatus. Mar Policy 55:73-80

Wetjen M, Wätjen K, Knust R (2014a) The role of the Antarctic silverfish Pleuragramma antarcticum in the Antarctic waters. In: Knust R, Schröder A (eds) The expedition PS82 of the Research Vessel Polarstern to the southern Weddell Sea in 2013/2014. Reports on Polar and Marine Research, Vol 680. Alfred Wegener Institute, Bremerhaven, p 103-105

Wetjen M, Wätjen K, Papetti C, Babbucci $M$ and others (2014b) Fish communities, distribution and production. In: Knust R, Schröder A (eds) The expedition PS82 of

Editorial responsibility: Stephen Wing,

Dunedin, New Zealand the Research Vessel Polarstern to the southern Weddell Sea in 2013/2014. Reports on Polar and Marine Research, Vol 680. Alfred Wegener Institute, Bremerhaven, p 99-103

White MG, Piatkowski U (1993) Abundance, horizontal and vertical distribution of fish in eastern Weddell Sea micronekton. Polar Biol 13:41-53

Whitworth T, Orsi AH, Kim SJ, Nowlin WD, Locarnini RA (1998) Water masses and mixing near the Antarctic Slope Front. In: Jacobs SS, Weiss RF (eds) Ocean, ice, and atmosphere: interactions at the Antarctic continental margin. American Geophysical Union, Washington, DC, p 1-27 Wöhrmann APA, Hagen W, Kunzmann A (1997) Adaptations of the Antarctic silverfish Pleuragramma antarcticum (Pisces: Nototheniidae) to pelagic life in high-Antarctic waters. Mar Ecol Prog Ser 151:205-218

* Youngs MK, Thompson AF, Flexas MM, Heywood KJ (2015) Weddell Sea export pathways from surface drifters. J Phys Oceanogr 45:1068-1085

Zane L, Marcato S, Bargelloni L, Bortolotto E and others (2006) Demographic history and population structure of the Antarctic silverfish Pleuragramma antarcticum. Mol Ecol 15:4499-4511

* Zhu G, Duan M, Ashford JR, Wei L, Zhou M, Bestley S (2018) Otolith nucleus chemistry distinguishes Electrona antarctica in the westward-flowing Antarctic Slope Current and eastward-flowing Antarctic Circumpolar Current off East Antarctica. Mar Environ Res 142:7-20

Submitted: July 27, 2018; Accepted: June 1, 2019

Proofs received from author(s): July 30, 2019 